\title{
The Application of Collaborative Writing Strategy in Teaching Composition in a Public Junior High School
}

\author{
Windy Puspitasari Suparto \\ Pascasarjana Universitas Negeri Makassar \\ windypuspitasari10@gmail.com
}

\begin{abstract}
Yusmah
Universitas Muhammadiyah Sidenreng Rappang yusmah.umsrappang@gmail.com

Nuraini Kasman

Universitas Muhammadiyah Sidenreng Rappang nurainikasman@gmail.com

Muhammad Amir

UIN Alauddin Makassar DPK STAI DDI Pinrang, muhamir0823@gmail.com
\end{abstract}

\author{
Abdul Wafi \\ IAIN MADURA \\ abdulwafi@iainmadura.ac.id
}

\begin{abstract}
The qualitative descriptive method was used by the researcher in this study. The term "qualitative descriptive research" refers to a survey study that determined and described the use of a collaborative writing strategy in teaching composition. The study's objectives are to learn how the teacher uses the collaborative writing strategy in teaching composition in a public junior high school, as well as the students' reactions to the strategies used by the teacher in teaching writing in a public junior high school. The teachers and students of UPT SMP Negeri 6 Makassar's ninth grade were the study's subjects. As a result, the researcher chose one of the two teachers at this school who could use Microsoft 365 and two classes, BI.2 and 9. A, as the subjects of the study. According to the findings, the English teacher at UPT SMP Negeri 6 Makassar frequently
\end{abstract}


employs three of five strategies, including horizontal division parallel writing, stratified division parallel writing, and reactive writing strategy. Furthermore, the researcher discovered that students' responses to the strategies that the teacher implemented in teaching writing of collaborative writing gave a positive response toward the collaborative writing strategy that the teacher used, and students' responses to the strategies that the teacher implemented in teaching writing tend to prefer groups in the form of group discussions rather than writing alone because they cannot exchange information and understanding. Because the students' background knowledge is still insufficient, the researcher discovered that group single author writing and sequential single writing are rarely used by the teacher during the research process.

Keywords: Collaborative Writing Strategy, Teaching Writing, Teaching Composition.

\section{INTRODUCTION}

The collaborative writing strategy is one of the most important writing strategies that students must learn (CWS). This ability is used in the academic context to assess students' collaborative writing proficiency, such as writing academic essays or curriculum-related texts. Group, pair, or individual work can be emphasized in composition instruction. According to Majlinda (2017), writing is a mode of speech that entails rational intervention in the printing of ideas and thoughts. Writing, according to Iskandar (2020, p.44), is the most difficult skill to teach when compared to other skills because when we teach writing, we also teach all other skills. Sanjaya, et al. (2020) claimed that writing is more than just a vehicle for communication; it also requires students to organize their information and put their ideas and thoughts into written form. Writing may also extend the author's expertise, allowing pupils to express their views more freely. There are many sorts of writing that students should concentrate on. There are four forms of writing: persuasive, descriptive, expository, and narrative (Oktavianti, et. al, 2021). This research contributes to a better understanding of the pedagogical approaches that teachers may employ depending on their particular context and the circumstances of their students.

The collaborative writing strategy research of Cristopher M. and Russell (2011, p.5) discovered that review a collaborative writing methodology designed for the authors' EFL university classes in which 
students work in pairs to produce co-authored paragraphs and essays. As a result, Grgonic (2005) discovered that collaborative writing is an effective writing technique that promotes cooperation, critical thinking, peer learning, and active participation in the creation of a final product. As a result, Stroch (2011) defines collaborative writing as the production of a text by two or more writers in collaboration.

Furthermore, Rollinson (2005) claims that the collaborative process can foster more independent writers by teaching them how to self-edit and revise their work. Collaborative writing allows students to learn multiple language skills more effectively than working alone. One of the primary causes of this phenomenon is that researchers overestimated theoretical assumptions and the reality gap.

The study was carried out by ninth-grade students at UPT SMP Negeri 6 Makassar. The researcher discovered a phenomenon in the collaborative writing strategy learning process in which students struggle with writing because they have not been able to develop this writing supported by students who still have a limited English vocabulary. Meanwhile, students have not received much information about the topics on which they wish to write; however, when they are grouped and discussed, students are better able to express their ideas and are more willing to share their knowledge. This study includes a review of related works of literature, the methodology of the study, and the results of the students' writing achievement after being taught the Collaborative Writing Strategy.

To summarize, a collaborative writing strategy is the ability to convey meanings to the reader through clear text as a result of some letter formation activity such as preparing, producing, and editing the text, which includes vocabulary, grammar, content, and mechanics. It is possible to conclude that a collaborative writing strategy is a discovery process involving a series of steps, and those steps are frequently a zigzag journey. The most important aspect of writing is that students are eager to learn how to write effectively. It means that through practice and the process of learning how to write, students can master writing skills. As a result, students can work together to create a good composition with their peers. The researchers classified the research questions based on the context as follows: 
1. How does the teacher apply the collaborative writing strategy in teaching composition at the ninth-grade students of UPT SMP Negeri 6 Makassar?

2. How are students' responses to the strategies that the teacher implemented inteaching writing at the ninth-grade students of UPT SMP Negeri 6 Makassar?

The objective of this research is to know how the teacher applies the collaborative writing strategy in teaching composition at the ninth-grade students of UPT SMP Negeri 6 Makassar and to know the students' responses to the strategies that the teacher implemented in teaching writing at the ninth-grade students of UPT SMP Negeri 6 Makassar. This research is expected to offer some benefits to students, English and future researchers. For the students, it can be a reference, if they want to conduct research related to the collaborative writing strategy. For English teachers hopefully, the result of this research can give information and to be good guidance in developing writing strategies. The research can be useful for the next researchers and provide additional information to the existing literature aboutthe application of collaborative writing strategy in teaching composition at the ninth-grade students of UPT SMP Negeri 6 Makassar.

\section{THEORETICAL FRAMEWORK}

\section{Collaborative Writing}

Collaborative writing is a method of teaching writing in which students write in groups, read and discuss their work, and evaluate it. It employs educational structures in which adolescents collaborate to plan, draft, rewrite, and revise their compositions. Collaborative writing entails developing teaching arrangements that allow teens to collaborate on the preparation, drafting, rewriting and editing of their writings. According to Bosley (1989), collaborative writing occurs when a small group of people collaborates to create a paper and a role clarification for the final product. In many cases, collaborative writing, according to Hadjerrouit (2011), creates opportunities for research studies or promotes thought, information exchange, or logical analysis. According to Nurhidayat et al. (2021), when writing a paragraph, authors should concentrate on the primary draft of the paragraph. Graham and Perin (2007) discovered that a collaborative writing strategy necessitates the development of educational strategies in which teenagers collaborate to prepare, script, rewrite, and change written work. A collaborative writing strategy, according to the definitions above, is the ability to communicate intended implications, 
ideas, and purposes to the reader through thinking, studying, developing, organizing, producing, revising, and editing the product.

In terms of collaborative writing tasks, Lunsford (1991) proposes three types of collaborative tasks that can be found in group projects in Sukirman (2016, p.34). Here are a few examples of collaborative writing assignments:

1. Higher-Order Reasoning Group members must define, discuss, and debate complex problems to solve them.

2. Division of Labor: Jobs that are too large for one person to complete in a reasonable amount of time must be divided.

3. Tasks requiring specialized knowledge or expertise, in which each collaborator brings a unique set of skills to the table.

\section{The Procedure of Collaborative Writing}

Mulligan (2011) discovered the following procedure for implementing collaborative writing:

1. Students chose their partners and exchanged contact information so that they could meet outside of class.

2. During class, pairs brainstormed ideas for the target topic and organized the information into coherent clusters.

3. Groups agreed to meet outside of class to do research and collect data for their papers.

4. Students worked in groups in class to create an outline, plan, and write the first draft.

5. The outlines were returned to the instructor, along with relevant comments.

6. Work on the first draft began.

7. The instructor reviewed the drafts, pointing out structural and organizational flaws as well as making comments and suggestions.

8. Work on the second draft has begun. For this section, students A and B switched roles. This time, Student B was tasked with typing the revision, while Student A was tasked with editing it. The second draft was then turned in.

9. Students received a single grade based on their overall effort and essay quality.

10. To ensure fairness, if a student was assigned the role of $A$ for the next writing assignment, they switched to the role of $B$, and vice versa.

11. The Elements of Writing 
To do good writing, certain aspects of writing are useful, and it is very important to be existing with us to do good writing. Nina (2016) has proved that there are crucial parts in a piece of writing, such as:

12. Ideas can take the form of an opinion, an experience, a feeling, knowledge, and so on.

13. It can be expressed in the form of an exposé and argumentation narrative.

14. Organization,

15. Communication methods or tools such as vocabulary, grammar, and style.

\section{Types of Collaborative Writing Strategy}

Several teachers have used collaborative writing in their writing classes. When implementing this strategy, they typically use a variety of collaborative writing strategies. In other words, they have opposing views on collaborative writing strategies. The following collaborative writing strategies have been proposed by some experts: Lowry (2004) distinguishes five types of collaborative writing strategies:

1) Group Single-Author Writing

It is a single person's writing that includes planning, drafting, and reviewing. Even if it is carried out by a single person, it is still a form of collaborative writing because it involves a group that works toward a collective consensus that is reflected in a document written by one of the team members. This happens when one of the team members writes as the team's representative. If the writing task is simple, this style of writing can be used. The structure of group single-author writing is depicted in the figure below.

2) Sequential Single Writing

One group member writes at a time in sequential singleauthor writing. Each member of the group is assigned a section of the document, writes their section, and then passes the document on to the next member of the group.

3) Horizontal Division Parallel Writing

When a group divides an assignment or document into sections and each member works on their assigned section at the same time, this occurs. Horizontal division parallel writing is possible if members of the group divide the task into sections, with each member responsible for developing the section to which they have been assigned. 
Windy, et.al: The Application of Collaborative Writing Strategy in Teaching Composition in a Public Junior High School - 305

4) Stratified Division Parallel Writing

It has been implemented if group members divide the responsibility of creating the product by assigning different roles to different members. Author, editor, facilitator, or team leader are some examples of roles that a member could be assigned.

5) Reactive Writing

It occurs when members of teamwork are in unison to create a product. Members of the team react to and adjust each other's contributions as they occur. Finally, mixed-mode collaborative writing entails combining two or more of the previously described collaborative writing strategies.

\section{RESEARCH METHODOLOGY}

In this study, the researcher employed the qualitative descriptive method. A survey study that determined and described the use of a collaborative writing strategy in teaching composition is referred to as "qualitative descriptive research." The goal of this research is to learn about the use of collaborative writing strategies in the composition classroom at UPT SMP Negeri 6 Makassar. The teachers and students of UPT SMP Negeri 6 Makassar's ninth grade are the subjects of the study. During the covid-19 pandemic, a lot of technology was used in the teaching and learning process. As a result, teachers must be able to use technology media in the teaching and learning process. Not all teachers have access to technology media, particularly Microsoft 365. As a result, the researcher chose one of the two teachers at this school who is capable of using Microsoft 365 and two classes, namely BI.2 and 9. The subjects of the study are A classes. There are four kinds of instruments used in this research, they are:

1) Researcher

In this research, the researcher herself acted as a nonparticipant observer who watched and observed directly the students' assignments in collaborative writing strategy but did not involve and interact with the students.

2) Observation Checklist

Observation checklist aimed at finding the teaching strategies used by the teachers. Each statement of the observation checklist offered two changes of scale namely: yes and no.

3) Video Recording

Data on the students' utterances in their writing activities were used to classify collaborative writing strategies. The 
students' utterances were recorded by using video recordings. Then, the researcher described the application used by the teacher in applying the collaborative writing strategy and students' responses to the collaborative writing strategies that the teacher implemented in teaching writing and reflective information. The researcher described the unexpected phenomena about the students' responses in collaborative writing strategy during the learning process.

4) Interview Questions

Interview questions were used to confirm teachers' and students' responses to the teacher's writing strategies. The purpose of the interview was to discover the teaching-learning process of collaborative writing strategy and to ask students about the different types of learning processes in collaborative writing strategy. Each interview statement included five questions for the teacher and five questions for the students. It sought to ascertain the factors of the learning process in collaborative writing strategy, as well as the students' reactions to the strategies used by the teacher in collaborative writing strategy in teaching composition.

The researcher analyzed the data by using the theory of Miles and Huberman models in Sugiyono (2016, p.338-345), namely:

1. Data Reduction

Data reduction referred to the process, where the mass of qualitative data she obtained from the observation checklist, video recording, and interview questions.

\section{Data Display}

To conclude the mass data, Miles and Huberman suggest that a good display of data, in the form of tables, charts, networks, and other graphical formats is essential. This is a continual process, rather than just one to be carried out at the end of the data collection.

\section{Data Verification}

The research analysis allowed the researcher to begin to develop conclusions regarding her study. These initial conclusions can then be verified, that is their validity examined through reference to theresearcher's existing field notes of further data collection. 


\section{RESULTS AND DISCUSSION \\ Results \\ Teacher's Application of Collaborative Writing}

This section presents the findings of the research's observation checklist. The findings on the type of collaborative writing used by the teacher in the classroom at UPT SMP Negeri 6 Makassar. Three collaborative writing strategies were used, namely horizontal division parallel writing, stratified division parallel writing, and reactive writing strategy.

\section{Horizontal Division Parallel Writing}

a. Teacher's understanding of Horizontal Division Parallel Writing According to the researcher's observations, the activities during the teaching and learning process were successful. The teacher was very good at managing the class. He could create a positive learning environment in the classroom. This was demonstrated by the students' eagerness to complete the teacher's assignments. He went through each step of the Horizontal Division Parallel Writing process step by step.

b. Teacher's application of Horizontal Division Parallel Writing

The result of the observation concerning with teacher's application of Horizontal Division Parallel Writing, it was true that the teacher applied the strategy very well.

\section{Stratified Division Parallel Writing}

a. Teacher's understanding of Stratified Division Parallel Writing To determine whether or not the teacher had a good understanding of Stratified Division Parallel Writing, the researcher directly observed how the teacher thought about the students in the classroom. To determine whether or not the procedures for implementing this strategy are followed. The researcher discovered that the activities that occurred during the teaching and learning process went well. In the classroom, he was effective. In the classroom, he was able to foster a positive learning environment. The students worked well in groups and completed the assignments assigned by the teacher. He excelled at every stage of Stratified Division Parallel Writing. The researcher discovered that the teaching activities utilizing the Stratified Division Parallel Writing strategy were successful after observing the teaching and learning process. The strategy's implementation steps went off without a hitch. The class was in session, and the students were fired up. He made the classroom a lively place. The 
teacher is knowledgeable about Stratified Division Parallel Writing.

b. Teacher's application of Stratified Division Parallel Writing The ability to apply the Stratified Division Parallel Writing could be proved by the result of the observation concerning this strategy applied by the teacher. The has proved that the teacher applied the strategy very well.

\section{Reactive Writing}

a. Teacher's understanding of Reactive Writing

The researcher conducted this observation to learn about the teacher's understanding of Reactive Writing. The researcher was confident that the teacher understood Reactive Writing because he observed how the teacher thought about the students in the classroom. To determine whether or not the procedures for putting this strategy into action are followed. The researcher discovered that the activities that took place during the teaching and learning process were successful. The classroom was clean and well-organized. The students took advantage of the pleasant classroom atmosphere. They were overjoyed with the teacher's assignments. Every step of the Reactive Writing process went off without a hitch. It meant that the teaching and learning process for the Reactive Writing Strategy had been a success.

It occurs when members of teamwork are in unison to create a product. Members of the team react to and adjust each other's contributions as they occur. Finally, the use of two or more of the previously discussed collaborative writing strategies is referred to as mixed mode. One of the most important things teachers should do before choosing one of the previously mentioned collaborative writing strategies is weighed the benefits and drawbacks of each strategy. Lowry (2004, p.81) discovered that to assist teachers in considering them, the researcher presents the table below, which discusses the advantages and disadvantages of the collaborative writing strategies proposed.

b. Teacher's application of Reactive Writing

Looking at the results of the researcher's observation reveals how the teacher used the Reactive Writing Strategy. The researcher was convinced that the teacher was an expert at using the Reactive Writing Strategy. It could be 
Windy, et.al: The Application of Collaborative Writing Strategy in Teaching Composition in a Public Junior High School - 309

demonstrated by the outcome of the teacher's observation of this strategy. She demonstrated that the teacher used the strategy effectively.

\section{Findings from the Interviews with the Teacher}

a. The Teacher's Understanding of Collaborative Writing Strategy

The teacher was asked five questions during the interview. The purpose of the data analysis was to learn more about the teacher's use of a collaborative writing strategy when teaching composition. According to the interview, the teacher believed that the Collaborative Writing Strategy was one of the recommended writing strategies for teaching composition in public junior high schools. The following collaborative writing strategies were used by the teacher: group single author writing, sequential single writing, horizontal division parallel writing, stratified division parallel writing, and reactive writing. The teacher was confident that if the collaborative writing strategy is used correctly in teaching composition at UPT SMP Negeri 6 Makassar, it will provide numerous benefits.

b. Teacher's Application of Collaborative Writing Strategy

The researcher discovered several opinions from the teacher in applying the Collaborative Writing Strategy in teaching writing for the ninth-grade students of UPT SMP Negeri 6 Makassar from the interviews conducted on Thursday, 8th April 2021 at 01.00-02.30 p.m. Here are the teacher's responses to five questions posed by the researcher about the Collaborative Writing Strategy that he used in teaching writing to students.

Montero demonstrated that the Collaborative Writing Strategy was not only a highly motivating learning experience for EFL/ESL students but also a creative pedagogical tool for teachers (2005, p.38). Horizontal Division Parallel Writing occurs when a group divides an assignment or document into separate parts and all members work on their assigned part at the same time, according to Lowry (2004, p.74-81).

As a result, Lowry (2004, pp.74-81) discovered that stratified division parallel writing is used when group members divide responsibility for product creation by assigning different members 
with different roles. Some examples of roles that a member could be assigned are author, editor, facilitator, or team leader.

Because of the stratified division of writing abilities, the teacher believed that each person plays a role in the project's composition process (Lowry, 2004). It indicates that the stratified division writing strategy was used by the teacher when teaching composition. The teachers' testimony indicates that they have a thorough understanding of the collaborative writing strategy and its components, as well as sufficient knowledge of how to implement collaboration in their classrooms.

\section{Students' responses to the strategies that the teacher implemented in teaching writing}

\section{Findings from the Interviews with the Students}

The researcher conducted interviews with students from Class 9.A. and Class 9.BI.2 on April 15, 2021, between 12.15 and 01.15 p.m. Five questions were asked of four students during the interview. The purpose of the data analysis was to discover the related and information about the teacher's use of collaborative writing strategy in composition teaching. From the first question of the interview, here are the students' responses to the teacher's strategies for teaching writing. The students stated that they understood the collaborative writing strategy used in learning writing, where they completed assignments in groups. It was simpler for them to do it in groups because they could share each other's work instead of doing it individually. Because individual and group assignments are the same.

Students stated that they understood the collaborative writing strategy in learning writing and preferred to complete assignments in groups in response to the second question. It was more convenient for them to do it in groups because they could share and discuss it with their friends rather than doing it individually. Because the assignments for individual work are the same as those for group work, they should work in groups. The teacher used this method by grouping students to work together to complete their assignments. They easily understood the assignments because the teacher would clearly explain the process instructions through a video conversation before they were given the assignments. 
In response to the third question, students stated that they were very familiar with the teacher's collaborative writing strategy for teaching writing. The teacher divided the students into several groups and then asked them to write some texts of the materials individually based on their understanding and then combine them with the ones that their group mates had written so that they could get a complete text. They preferred working on the assignments in groups because it allowed them to discuss, share, and correct each other when they encountered difficulties or disagreements.

Students stated that they understood the teacher's learning strategy in response to the fourth question. They could perform admirably on the teacher's assignments if he assigned them in groups. It would be easier, particularly if you combined ideas from other friends. It was advantageous to form good working relationships with friends. They understood the teacher's assignments, whether handwritten or typed on a computer. In response to the fifth question, the student stated that they never had a problem completing the assignments assigned by the teacher because they did it in groups. If they were having difficulties, they would seek assistance from the teacher or their peers.

The teacher employed three strategies: horizontal division of parallel writing, stratified division of parallel writing, and reactive writing. The teacher rarely used sequential single writing and group single author writing. The use of a collaborative writing strategy in teaching composition at UPT SMP Negeri 6 Makassar is critical to reducing student boredom.

\section{Discussion}

The researcher presented a discussion of the findings after analyzing the data. In terms of the findings data, the researcher discovered that the information was gathered through the teacher's responses in the interview. The researcher examined each interview question to reach a comprehensive conclusion. The following is the analysis:

The instructional principles and strategies comprise a teaching composition. Sukirman (2016, p.34) proposes three types of collaborative tasks that should be included in group projects, according to Lunsford. Examples of collaborative writing tasks include: HigherOrder Thinking To solve complex problems, members of a group must define, discuss, and debate. Labor division: Large jobs that cannot be 
completed by one person in a reasonable amount of time must be divided. Specialist or expertise-based Tasks, each collaborator brings a unique set of skills to the table. The collaborative writing strategy used in composition classes is heavily influenced by the information taught, but it can also be influenced by the student's aptitude and enthusiasm.

The researcher concluded the first meeting, which took place on Thursday, March 25th, 2021 from 09.30 a.m. until 12 a.m. That is the teacher in Class 9. A had a good understanding of how to use Horizontal Division Parallel Writing in teaching writing. Lowry et al. (2004, pp.7481) discovered that occurs when a group divides an assignment or document into separate parts and all members work on their assigned part simultaneously. It means that horizontal division parallel writing is feasible if group members divide the task into sections, with each member responsible for the development of his or her assigned section. As a result, the researcher discovered that horizontal division parallel writing occurs when each person completes one part of a larger project and then compiles it.

The teacher has been informed that Stratified Division Parallel Writing will be used in the second meeting on Thursday, April 1st, 2021, beginning at 09.30 a.m. until 12 a.m. in 9th grade. A. Lowry et al. (2004, pp.74-81) discovered that stratified division parallel writing is used when members of a group divide responsibility for product creation by assigning different roles to different members. Author, editor, facilitator, or team leader are some examples of roles that a member could be assigned. Furthermore, according to the researcher, stratified division writing is a process in which each person contributes to the composition of a project based on their abilities.

Reactive Writing will be used in the third meeting, which will begin at 9:30 a.m. on Thursday, April 8, 2021. until midnight in 9th grade BI.2. According to Lowry et al. (2004, p.74-81), reactive writing occurs when team members collaborate synchronously to develop their product. Members of the team react to and adjust each other's contributions as they occur. Finally, the use of two or more of the previously discussed collaborative writing strategies is referred to as mixed mode.

\section{CONCLUSION}

The researcher discovered, based on the findings and discussions, that Lowry et al. (2004, p.74-81) proposed five types of collaborative writing strategies, namely: group single author writing, sequential single writing strategy, horizontal division parallel writing, 
stratified division parallel writing, and reactive writing strategy, that the application of collaborative writing strategy in teaching composition in a public junior high school. According to research, three of five methods are frequently used by the English teacher at UPT SMP Negeri 6 Makassar, including horizontal division parallel writing, stratified division parallel writing, and reactive writing strategy. Furthermore, the researcher discovered that students' responses to the strategies that the teacher used in teaching writing of collaborative writing gave a positive response toward the collaborative writing strategy that the teacher used, and students' responses to the strategies that the teacher used in teaching writing tend to prefer groups in the form of group discussions rather than writing alone because they cannot exchange information and understanding. Finally, the researcher discovered that teachers rarely use group single author writing and sequential single writing during the research process because students' background knowledge is still insufficient.

\section{REFERENCES}

Applebee, A. (1986). The problem in process approaches. In Anthony R. Petrosky and David Bartholomae (Eds.),The teaching of writing. Distributed by The University of Chicago Press.

Bosley, D. S. (1989). A National Study of the Uses of Collaborative Writing in Business Communication Courses among Members of the $A B C$ [Unpublished Doctoral Dissertation]. Illinois State University.

Graham, S., \& Perin, D. (2007). A meta-analysis of writing instruction for adolescent students. Manuscript submitted for publication.

Grgonic, Natalija, Raden, \& Orgjen. (2005). Classroom Practice: Collaborative Writing. ENGL.

Hadjerrouit, S. (2011). A Collaborative Writing Approach to Wikis: Design, Implementation, and Evaluation. Issues in Informing Science and Information Technology, 8, 431-449.

Hayes, J. R., \& Flower, L. S. (1980). Identifying the organization of writing processes. In Lee W. Gregg \& Erwin R. Steinberg (Eds.), Cognitive Processing Writing. Lawrence Erlbaum.

Hayes, J. R., \& Flower, L. S. (1983). Uncovering cognitive processes in writing: An introduction to protocol analysis. In Peter Mosenthal, $L$. Tamor, \& S. A. Walmsley (Eds.), Research on Writing: Principles and methods. Longman. 
Knudson, R. E. (1991). Effects of instructional strategies, grade, and sex on students' persuasive writing. Journal of Experimental Education, 59, 141- 152.

Lika. Majlinda. (2017). IJAEDU - International E - Journal of Advances In Education. Retrieved from: http://ijaedu.ocerintjournals.org.com. Lowry, P. B., Curtis, A., \& Lowry, M. R. (2004). Building a Taxonomy and Nomenclature of Collaborative Writing to Improve Interdisciplinary Research and Practice. Journal of Business Communication, 41(66), 74-81.

Lunsford, A. (1991). Collaboration, Control, and the Idea of a Writing Center. The Writing Center Journal, 12(1), 3-10.

Nagin, C. (2003). Because writing matters: Improving student writing in our schools. San Francisco, CA: Jossey-Bass.

Nina, K. V. (2016). Teaching Writing Skills by Using Brain writing. OKARA:Journal of Languages and Literature, 1(1).

Montero, A. (2005). What a feeling! Motivating EFL students through collaborative writing with poems. English Teaching Forum, 43(3), 36-38.

Mulligan, Christopher, \& Garofalo, R. (2011). A Collaborative Writing Approach: Methodology and Students Assessment.

Nina, K. V. (2016). Teaching Writing Skills by Using Brainwriting. OKARA: Journal of Languages and Literature, 1.

Nurhidayat, E. F., Apriani, E., \& Edy, S. (2021). The Analysis of Cohesive Devices used by Tertiary English Students in Writing English paragraphs. International Journal of Multicultural and Multireligious Understanding, 8(4), 70-81.

Oktavianti, D., Gusmuliana, P., \& Apriani, E. (2021). The Students' Strategies in Developing Their Ideas in Writing Essay. Jadila: Journal of Development and Innovation in Language and Literature Education, 1(4), 389-406.

Oxford. R. L. (1990). Language Learning Strategies: What Every Teacher Should Know. New York: Newbury House.

Rohman, D. G., \& Wlecke, A. O. (1965). Pre-writing: The construction andapplication of models for concept formation in writing (U.S. Office of Education Cooperative Research Project No. 2174).

Rollinson, P. (2005). Using peer feedback in the ESL writing class. ELT Journal.

Saddler, B., \& Graham, S. (2005). The effects of peer-assisted sentencecombining Instruction On The writing performance of more and less skilled young writers. Journal of Educational Psychology, 97, 4354. 
Windy, et.al: The Application of Collaborative Writing Strategy in Teaching Composition in a Public Junior High School - 315

Sanjaya, H. K., Apriani, E., \& Edy, S. (2020). Using web blogs in teaching writing for EFL students. Journal of English Education and Teaching (JEET), 4(4), 516-535.

Stroch, N. (2011). Annual review of applied linguistic. CambridgeUniversityPress. 
316 | ENGLISH FRANCA, Vol. 5, No. 2, 2021 